\title{
FAKTOR DETERMINAN DARI COST OF FINANCIAL DISTRESS
}

\section{(Studi Empiris pada Perusahaan Tekstil dan Garmen di Indonesia Tahun 2014-2017)}

\begin{abstract}
This study aims to examine the factors that influence cost of financial distress through liquidity, activity, leverage, and firm size. The company used in this study is a company listed on the Indonesia Stock Exchange in 2014-2017. The number of research sample is 11 companies selected using the purposive sampling method with observations for four years. The analysis technique used in this study is the panel data regression method using Eviews software. The result shows that liquidity, activity, leverage, and firm size simultaneusly have a significant effect on cost of financial distress. Partially, liquidity has positive significant effect on cost of financial distress, firm size has negative significant effect on cost of financial distress. Activity and leverage have no effect on cost of financial distress.
\end{abstract}

\begin{abstract}
ABSTRAK: Penelitian ini dilakukan untuk meneliti faktorfaktor yang mempengaruhi cost of financial distress melalui likuiditas, aktivitas, leverage, dan ukuran perusahaan. Perusahaan yang digunakan yaitu perusahaan sub sektor tekstil dan garmen yang terdaftar di Bursa Efek Indonesia pada tahun 2014-2017. Jumlah sampel penelitian yaitu 11 perusahaan, dipilih menggunakan metode purposive sampling dengan pengamatan selama empat tahun. Teknik analisis yang digunakan yaitu regresi data panel dengan menggunakan software Eviews. Berdasarkan hasil penelitian, likuiditas, aktivitas, leverage, dan ukuran perusahaan secara simultan berpengaruh signifikan terhadap cost of financial distress. Secara parsial, likuiditas berpengaruh positif terhadap cost of financial distress, ukuran perusahaan berpengaruh negatif terhadap cost of financial distress. Sedangkan aktivitas dan leverage tidak berpengaruh terhadap cost of financial distress.
\end{abstract}

\author{
Aninditya Cindy Natasya ${ }^{1}$, \\ Farida Titik Kristanti ${ }^{2}$ \\ 1,2 Jurusan Akuntansi \\ Fakultas Ekonomi Dan Bisnis \\ Universitas Telkom \\ Bandung, Jawa Barat \\ E-mail: \\ anindityanatasya@gmail.com \\ Keywords: Activity; Cost of \\ Financial Distress; \\ Leverage; Liquidity; Size
}

Kata Kunci: Aktivitas; Cost of

Financial Distress;

Leverage; Likuiditas;

Ukuran Perusahaan 


\section{PENDAHULUAN}

Suatu perusahaan didirikan untuk menjalankan usaha pokok yang akhirnya akan memperoleh keuntungan. Perusahaan perlu menjaga stabilitas agar keberlangsungan usaha dapat terus berlanjut dan bersaing dengan para kompetitor. Apabila perusahaan tidak dapat bersaing dan menjaga stabilitas, maka hal tersebut dapat memperbesar potensi terjadinya kesulitan keuangan.

Perusahaan tekstil dan garmen sedang melemah akibat dampak dari permintaan yang terus menurun secara global. Hal tersebut dapat dilihat dari nilai earning per share (EPS) perusahaan yang negatif selama empat tahun terakhir. Dari 18 perusahaan yang terdaftar, terdapat 8 perusahaan yang memiliki EPS negatif tahun 2014 dan 2015. 7 perusahaan memiliki EPS negatif tahun 2016, namun mengalami kenaikan kembali di angka 8 tahun 2017. Perusahaan yang memiliki EPS negatif merupakan perusahaan yang mengalami financial distress (Elloumi dan Gueyie, 2001). Jika perusahaan terus mengalami situasi ini, maka keberlangsungan perusahaan terganggu dan kemungkinan berpotensi mengalami financial distress.

Financial distress yaitu situasi ketika perusahaan tidak mampu membayar kewajibannya, yang akan menyebabkan peningkatan biaya (Kristanti, 2015). Ketika perusahaan mengalami financial distress, maka perusahaan tersebut akan bertemu lebih banyak biaya daripada perusahaan yang tidak mengalami financial distress, Hal tersebut dapat menurunkan nilai perusahaan. Cost of financial distress merupakan pengurangan nilai karena dianggap tidak mampu memenuhi pembayaran tetap di masa depan dan berpotensi untuk mengalami proses kebangkrutan berikutnya (Branch 2002). Studi empiris membagi dua tipe cost of financial distress, yaitu direct cost dan indirect cost. Direct cost terdiri dari biaya administrasi yang berbeda dan berkaitan dengan kebangkrutan, reorganisasi, proses likuidasi, atau biaya kebangkrutan lainnya. Indirect cost didefinisikan sebagai biaya alternatif atau peluang yang terlewatkan.

Kesulitan keuangan dapat dialami perusahaan, salah satu faktor penyebabnya yaitu adanya kinerja keuangan yang dinilai kurang baik. Rasio likuiditas, rasio aktivitas, dan rasio leverage diindikasi mempengaruhi cost of financial distress. Faktor lainnya yang dapat mempengaruhi cost of financial distress yaitu ukuran perusahaan.

Penelitian ini bertujuan untuk mengetahui kondisi terhadap faktor-faktor yang mempengaruhi cost of financial distress melalui likuiditas, aktivitas, leverage, dan ukuran perusahaan. Penelitian ini juga dapat menunjukkan ada atau tidaknya pengaruh dari likuiditas, aktivitas, leverage, dan ukuran perusahaan terhadap cost of financial distress, baik simultan maupun parsial.

\section{PENGEMBANGAN HIPOTESIS}

\subsection{Dasar teori}

\subsubsection{Teori Sinyal}

Teori sinyal (signalling theory) adalah teori yang melandasi penggukapan sukarela dimana manajemen selalu ingin menunjukan berita baik kepada calon investor dan pemegang saham meskipun bersifat privasi (Muflihah, 2017). Sinyal tersebut berupa informasi terkait apa saja yang sudah dilakukan oleh manajemen untuk merealisasi keinginan para pemilik. Informasi yang dikeluarkan oleh perusahaan merupakan hal yang penting, karena informasi tersebut akan berpengaruh terhadap keputusan investasi pihak di luar perusahaan. 


\subsubsection{Likuiditas}

Rasio likuiditas yaitu rasio yang menggambarkan kemampuan perusahaan memenuhi kewajiban jangka pendeknya yang akan jatuh tempo (Hery 2016:149). Likuiditas menunjukkan posisi arus kas jangka pendek yang menjadi penentu secara langsung pada kemampuan perusahaan untuk bertahan hidup ketika perusahaan mengalami kesulitan keuangan (Kristanti dan Isynuwardhana, 2018). Current ratio menjadi indikator likuiditas dalam penelitian ini dan digunakan untuk menggambarkan kemampuan total aset yang dimiliki perusahaan melunasi kewajiban jangka pendek yang segera jatuh tempo. Rumus yang digunakan yaitu (Hery 2016:152):

$$
\mathrm{CR}=\frac{\text { Aset Lancar }}{\text { Kewajiban Lancar }}
$$

\subsubsection{Aktivitas}

Rasio aktivitas yaitu rasio untuk mengukur tingkat efisiensi atas pemanfaatan sumber daya yang dimiliki perusahaan, atau untuk menilai kemampuan perusahaan dalam menjalankan aktivitas sehari-hari (Hery 2016:143). Total assets turnover menjadi indikator rasio aktivitas dalam penelitian ini. Ketika sebuah perusahaan menggunakan sumber daya secara efisien, maka hal tersebut mencerminkan perusahaan yang baik. Rumus yang digunakan yaitu (Hery 2016:143):

$$
\text { TATO }=\frac{\text { Penjualan }}{\text { Total Aset }}
$$

\subsubsection{Leverage}

Rasio leverage merupakan rasio yang mampu menggambarkan kemampuan perusahaan dalam memenuhi seluruh kewajibannya (Fahmi 2014:127). Rasio ini menggambarkan sejauh mana dana pinjaman tersebut digunakan untuk membeli aset. Debt to asset ratio menjadi indikator dalam penelitian ini. Rumus yang digunakan yaitu (Fahmi 2014:127):

$$
\text { DAR }=\frac{\text { Total Hutang }}{\text { Total Aset }}
$$

\subsubsection{Ukuran Perusahaan}

Ukuran perusahaan adalah skala yang dapat klasifikasi besar kecil perusahaan (Wardhani dan Mulid, 2017). Dalam penelitian ini, indikator yang digunakan adalah log natural (Ln) total aset. Semakin besar total aset perusahaan, maka semakin besar ukuran perusahaan tersebut begitu juga sebaliknya. Rumus yang digunakan yaitu (Harahap 2013:23):

$$
S I Z E=\text { Ln Total Aset }
$$

\subsubsection{Financial Distress}

Financial distress juga dapat diartikan sebagai ketidakmampuan perusahaan untuk membayar kewajiban keuangannya pada saat jatuh tempo yang menyebabkan kebangkrutan atau kesulitan likuiditas yang mungkin sebagai awal kebangkrutan (Rudianto, 2013:251).

\subsubsection{Cost of Financial Distress}

Cost of financial distress merupakan pengurangan nilai karena dianggap tidak mampu memenuhi pembayaran tetap di masa depan dan berpotensi untuk mengalami proses kebangkrutan berikutnya (Branch 2002). Rumus yang digunakan yaitu (Lopez-Gracia dan Sanches-Andujar, 2007)

$$
C F D=\frac{\text { Standar deviasi EBIT }- \text { Mean EBIT }}{\text { Total Aset }}
$$




\subsection{Kerangka Pemikiran}

\subsubsection{Pengaruh Rasio Likuiditas Terhadap Cost of Financial Distress}

Perusahaan harus memiliki aset lancar yang lebih besar dibandingkan dengan utang lancar agar perusahaan dapat bertahan dalam kondisi likuid. Jika kewajiban jangka pendek sebuah perusahaan dapat terpenuhi tepat waktu, maka perusahaan dapat terhindar dari kondisi financial distres serta terhindar dari cost of financial distress.

\section{$\mathrm{H}_{1}$ : Likuiditas berpengaruh negatif terhadap cost of financial distress}

\subsubsection{Pengaruh Rasio Aktivitas Terhadap Cost of Financial Distress}

Ketika sebuah perusahaan menggunakan sumber daya secara efisien, maka hal tersebut mencerminkan perusahaan yang baik. Jika penjualan meningkat dibandingkan dengan peningkatan aktiva, rasio ini akan semakin tinggi. Hal tersebut juga akan berpengaruh pada profitabilitas perusahaan karena perusahaan akan memperoleh dana dari penjualan. Maka kemungkinan perusahaan mengalami financial distress semakin kecil. Cost of financial distress juga semakin menurun disebabkan rasio aktivitas yang tinggi.

\section{H2: Aktivitas berpengaruh negatif terhadap cost of financial distress}

\subsubsection{Pengaruh Rasio Leverage Terhadap Cost of Financial Distress}

Leverage yang tinggi menunjukkan bahwa bahwa utang yang digunakan untuk membiayai aset perusahaan semakin tinggi, dan sebaliknya. Jika total hutang yang dimiliki perusahaan semakin besar, maka hal tersebut dapat memperkecil laba yang akan diperoleh perusaahan. Hal tersebut dapat mengakibatkan kemungkinan perusahaan mengalami financial distress dan secara positif mempengaruhi cost of financial distress.

H3: Leverage berpengaruh positif terhadap cost of financial distress

\subsubsection{Pengaruh Ukuran Perusahaan} Terhadap Cost of Financial Distress

Perusahaan yang memiliki aset yang besar dapat menunjukkan sinyal untuk para investor maupun kreditur yang akan melakukan investasi maupun memberikan kredit. Jika perusahaan memiliki total aset yang kecil, maka perusahaan tidak dapat melakukan investasi baik untuk aset lancar maupun aset tetap. Hal tersebut dapat meningkatkan kemungkinan perusahaan mengalami financial distress dan juga meningkatkan cost of financial distress.

H4: Ukuran perusahaan berpengaruh negatif terhadap cost of financial distress

\section{METODE, DATA, DAN ANALISIS}

Penelitian ini menggunakan metode kuantitatif dan berdasarkan tujuannya yaitu bersifat deskriptif. Penelitian ini menggunakan 11 perusahaan tekstil dan garmen yang terdaftar di Bursa Efek Indonesia periode 20142017 dengan teknik purposive sampling. Kriterianya yaitu (1) perusahaan tekstil dan garmen yang terdaftar di BEI pada 2014-2017 dan (2) perusahaan tekstil dan garmen yang konsisten menerbitkan dan mempublikasikan laporan keuangan dan laporan tahunan berturut-turut selama periode 2014-2017 di BEI. Dengan kriteria tersebut, maka diperoleh 44 total sampel.

Penelitian ini menggunakan analisis regresi data panel sebagai teknik analisis data, persamaannya adalah sebagai berikut: 


$$
\begin{aligned}
\mathrm{FDIC}= & \alpha+\beta_{1} \mathrm{CR}+\beta_{2} \mathrm{TATO}+\beta_{3} \mathrm{DAR}+ \\
& \beta_{4} \mathrm{SIZE}+\varepsilon
\end{aligned}
$$

Keterangan:

FDIC : Cost of financial distress

$\alpha \quad$ : Konstanta

$\beta_{1}, \beta_{2}, \beta_{3}$, : Koef. regresi variable

$\beta_{4}, \beta_{5}$

CR : Rasio likuiditas

$\begin{array}{lll}\text { TATO } & : & \text { Rasio aktivitas } \\ \text { DAR } & : & \text { Rasio leverage } \\ \text { SIZE } & : & \text { Ukuran perusahaan } \\ \text { E } & : & \text { Tingkat error }\end{array}$

HASIL DAN PEMBAHASAN

4.1 Hasil Penelitian

4.1.1 Analisis Statistik Deskriptif

Tabel 2. Hasil Analisis Statistik Deskriptif

\begin{tabular}{llllll}
\hline \multicolumn{2}{l}{ Descriptive Statistics } & & & & \\
& $\mathrm{N}$ & Minimum & Maximum & Mean & $\begin{array}{l}\text { Std. } \\
\text { Deviation }\end{array}$ \\
\hline CR & 44 & 0.1064 & 4.5808 & 1.2809 & 1.0558 \\
TATO & 44 & 0.1863 & 1.8078 & 0.8354 & 0.4891 \\
DAR & 44 & 0.2000 & 5.0700 & 1.0402 & 1.2574 \\
SIZE & 44 & 12.9631 & 16.2433 & 14.2962 & 1.0471 \\
Valid N & 44 & & & & \\
(listwise) & & & & & \\
\hline
\end{tabular}

Sumber: Diolah oleh penulis (2019)

Tabel 2 menjelaskan bahwa nilai rata-rata rasio likuiditas $\left(\mathrm{X}_{1}\right)$ sebesar 1.2809 dan nilai standar deviasi sebesar 1.0558. Hasil tersebut menunjukan bahwa variabel current ratio memiliki data yang tidak bervariasi. Nilai maksimum current ratio sebesar 4.5808 dan nilai minumum sebesar 0.1064 .

Rata-rata rasio aktivitas $\left(\mathrm{X}_{2}\right)$ sebesar 0.8354 dan nilai standar deviasi sebesar 0.4891 . Hasil tersebut menunjukan bahwa variabel total asset turnover memiliki data yang tidak bervariasi. Nilai maksimum variabel total asset turnover adalah sebesar 1.8078 dan nilai minumum sebesar 0,1863

Rata-rata rasio leverage $\left(\mathrm{X}_{3}\right)$ sebesar 1.0402 dan nilai standar deviasi sebesar 1.2574. Hasil tersebut menunjukan bahwa variabel debt to asset ratio memiliki data yang bervariasi. Nilai maksimum variabel debt to asset ratio adalah sebesar 5.0700 dan nilai minumum sebesar 0.2000.
Rata-rata ukuran perusahaan $\left(\mathrm{X}_{4}\right)$ sebesar 14.2962 dan nilai standar deviasi sebesar 1.0471. Hasil tersebut menunjukan bahwa variabel debt to asset ratio memiliki data yang tidak bervariasi. Nilai maksimum ukuran perusahaan adalah sebesar 16.2433 dan nilai minumum sebesar 12.9631

\subsubsection{Uji Asumsi Klasik}

Fungsi dari uji asumsi klasik yaitu untuk memastikan nilai-nilai koefisien penduga yang dihasilkan menjadi tidak bias. Uji yang dilakukan adalah uji asumsi klasik yaitu uji normalitas, uji multikolinearitas, serta uji heteroskedastisitas.

\section{Uji Normalitas}

Uji Jarque-Bera menjadi salah satu cara untuk menguji normalitas dan metode ini adalah metode yang banyak digunakan. Selain itu uji Jarque-Bera mempunyai nilai chi square dengan derajat bebas dua. 


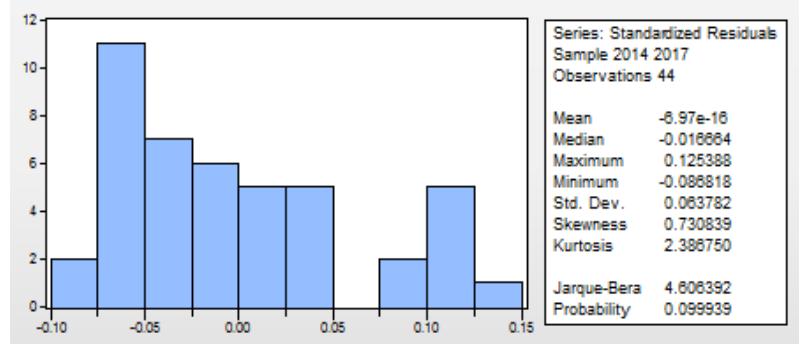

Gambar 1 Hasil Uji Normalitas

Sumber: Output Eviews 9.0

Gambar 1 menunjukkan perolehan nilai probabilitas JB (Jarque-Bera) 0,099939. Hasil uji jarque-bera lebih besar dari nilai chi square pada $\alpha=5 \%$. Hal tersebut menunjukkan bahwa H0 diterima dan data residual terdistribusi normal.

\section{Uji Multikolinearitas}

Selanjutnya yaitu dilakukan uji multikolinearitas. Jika nilai koefisien korelasi yang dimiliki antar variabel bebas yang digunakan < 0,8 maka penelitian ini tidak terjadi multikolinieritas.

Tabel 3. Uji Multikolinieritas

\begin{tabular}{lllll}
\hline & CR & TATO & DAR & SIZE \\
\hline CR & 1.0000 & 0.0436 & -0.4476 & 0.1527 \\
TATO & 0.0436 & 1.0000 & 0.5262 & 0.1327 \\
DAR & -0.4476 & 0.5262 & 1.0000 & 0.2508 \\
SIZE & 0.1527 & 0.1327 & 0.2508 & 1.0000 \\
\hline
\end{tabular}

Sumber: Output Eviews 9.0

Uji multikolinearitas pada tabel 3 menunjukkan bahwa seluruh variabel nilai koefisien lebih kecil dari 0,8. Maka multikolinieritas tidak terjadi dalam penelitian ini.

\section{Uji Heteroskedastisitas}

Lalu, uji yang terakhir dilakukan dalam penelitian ini yaitu uji heteroskedastisitas dengan menggunakan uji glejser. Ketika nilai probabilitas (prob) > 0,05 maka tidak terjadi heteroskedastisitas dalam data penelitian.

Tabel 4. Uji Heteroskedastisitas

\begin{tabular}{lllll}
\hline Var. & Coefficient & $\begin{array}{l}\text { Std. } \\
\text { Error }\end{array}$ & t-Statistic & Prob. \\
\hline C & 0.223029 & 0.144196 & 1.546706 & 0.1300 \\
CR & -0.001888 & 0.006783 & -0.278270 & 0.7823 \\
TATO & -0.015884 & 0.018071 & -0.878975 & 0.3848 \\
DAR & -0.006729 & 0.008729 & -0.770867 & 0.4454 \\
SIZE & -0.010386 & 0.010215 & -1.016789 & 0.3155 \\
\hline
\end{tabular}

Sumber: Output Eviews 9.0

Tabel 4 menunjukkan bahwa dalam penelitian ini heteroskedastisitas tidak terjadi karena setiap variabel independen memiliki nilai probabilitas diatas 0,05 .

\subsubsection{Analisis Regresi Data Panel}

Pengujian model regresi data panel telah dilakukan dan random effect dipilih sebagai model terbaik. Pada tabel 5, dapat dilihat bahwa hasil uji $\mathrm{F}$ menunjukkan likuiditas, aktivitas, leverage, dan ukuran perusahaan berpengaruh simultan terhadap cost of financial distress. Variabel independen mampu menjelaskan variabel dependen sebesar 74,06\%. Hal tersebut menjelaskan bahwa adanya hubungan yang kuat antara likuiditas, aktivitas, leverage, dan ukuran perusahaan dengan cost of financial distress, serta menunjukkan bahwa model penelitian ini cukup baik. Selanjutnya, hubungan secara parsial dalam penelitian ini akan dijelaskan sebagai berikut: 
Tabel 5. Hasil Uji Statistik Model Random Effect

\begin{tabular}{lcccc}
\hline \multicolumn{1}{c}{ Variable } & Coefficient & Std. Error & t-Statistic & Prob. \\
\hline C & 2.600390 & 0.235032 & 11.06397 & 0.0000 \\
CR & 0.028080 & 0.009976 & 2.814756 & 0.0076 \\
TATO & -0.019704 & 0.027810 & -0.708516 & 0.4828 \\
DAR & -0.004303 & 0.013890 & -0.309753 & 0.7584 \\
SIZE & -0.166669 & 0.016581 & -10.05156 & 0.0000 \\
\hline \multicolumn{5}{c}{ Weighted Statistics } \\
\hline R-squared & 0.764754 & Mean dependent var. & 0.024682 \\
Adjusted R- & \multicolumn{5}{c}{ S.D. dependent var. } & 0.030687 \\
squared & 0.740626 & Sum squared resid & 0.009526 \\
S.E. of regression & 0.015628 & Durbin-Watson stat. & 1.726158 \\
F-statistic & 31.69593 & & \\
Prob(F-statistic) & 0.000000 & &
\end{tabular}

Tabel 5 menunjukkan variabel likuiditas (X1) memiliki nilai probabilitas $0.0076<0,05$ $(\alpha=5 \%)$ sehingga $\mathrm{H} 1$ diterima, yaitu likuiditas berpengaruh signifikan dan positif terhadap cost of financial distress. Variabel aktivitas (X2) memiliki nilai probabilitas $0.4828>0,05$ $(\alpha=5 \%)$. Maka keputusan yang diambil yaitu menolak $\mathrm{H} 2$ dan mengartikan bahwa aktivitas tidak berpengaruh signifikan terhadap cost of financial distress. Variabel leverage (X3) memiliki nilai probabilitas $0.7584>0,05$ $(\alpha=5 \%)$. Maka keputusan yang diambil adalah menolak $\mathrm{H} 3$, leverage tidak berpengaruh terhadap cost of financial distress secara signifikan. Nilai probabilitas dari ukuran perusahaan (X4) $0.0000<0,05 \quad(\alpha=5 \%)$ sehingga keputusan yang diambil adalah menerima $\mathrm{H} 4$, yaitu ukuran perusahaan berpengaruh signifikan dan negatif terhadap cost of financial distress.

\subsection{Pembahasan Hasil Penelitian}

Dari hasil uji di atas, dapat dilihat bahwa variabel likuiditas (X1) berpengaruh signifikan dan positif terhadap cost of financial distress. Penelitian ini menggambarkan bahwa current ratio yang lebih besar dapat mengindikasikan likuiditas aset lancar yang rendah. Perputaran aset lancar hanya digunakan untuk memenuhi kewajiban lancar dan kegiatan operasi harian. Dana perusahaan hanya bertahan di perusahaan dan tidak digunakan secara efektif dalam kegiatan investasi. Kemungkinan perusahaan mengalami kondisi financial distress saat perusahaan memiliki current ratio yang tinggi, hal tersebut juga meningkatkan cost of financial distress. Penelitian ini selaras dengan penelitian Wijarnarto dan Nurhidayati (2016) serta Haq (2013) bahwa likuiditas memiliki pengaruh positif terhadap financial distress.

Variabel aktivitas (X2) tidak berpengaruh signifikan terhadap cost of financial distress. Hal ini bertentangan dengan hipotesis yang telah dibangun oleh penulis yang menyatakan bahwa aktivitas berpengaruh signifikan negatif terhadap cost of financial distress. Dari hasil tersebut, dapat disimpulkan bahwa ketika perusahaan memiliki total asset turnover tinggi maupun rendah, perusahaan tersebut dapat mengalami financial distress serta akan adanya cost of financial distress. Penelitian ini selaras dengan penelitian Saleh dan Sudiyatno (2013) dan 
Nakhar et al (2017) bahwa aktivitas tidak memiliki pengaruh terhadap financial distress. Variabel leverage (X3) tidak berpengaruh terhadap cost of financial distress secara signifikan. Dapat disimpulkan bahwa ketika perusahaan memiliki debt to asset ratio tinggi maupun rendah, perusahaan tersebut dapat mengalami financial distress serta akan adanya cost of financial distress. Penelitian ini selaras dengan penelitian Widhiari dan Merkusiwati (2015) bahwa leverage tidak memiliki pengaruh terhadap financial distress. Variabel ukuran perusahaan (X4) berpengaruh signifikan dan negatif terhadap cost of financial distress. Perusahaan tidak mampu untuk investasi aset lancar maupun aset tetap ketika perusahaan mempunyai total aset yang kecil. Hal tersebut mampu meningkatkan kemungkinan perusahaan untuk mengalami financial distress dan juga meningkatkan cost of financial distress. Penelitian yang dilakukan Susilawati et al (2017) serta Kristanti dan Effendi (2017) mendukung penelitian ini, yaitu ukuran perusahaan memiliki pengaruh negatif terhadap financial distress serta Wijantini (2007) yang mengemukakan bahwa indirect cost of financial distress berpengaruh secara signifikan oleh ukuran perusahaan.

\section{KESIMPULAN, KETERBATASAN DAN SARAN}

\subsection{Kesimpulan}

Berdasarkan penjelasan di atas, kesimpulannya yaitu likuiditas, aktivitas leverage, dan ukuran perusahaan berpengaruh signifikan dalam memprediksi cost of financial distress pada sub sektor tekstil dan garmen yang terdaftar di BEI tahun 2014-2017. Likuiditas memiliki pengaruh positif dan ukuran perusahaan berpengaruh secara negatif terhadap cost of financial distress. Sementara aktivitas dan leverage tidak berpengaruh signifikan dalam memprediksi cost of financial distress.

\subsection{Keterbatasan dan Saran}

Untuk peneliti selanjutnya, diharapkan adanya tambahan dan penggunaan proksi lainnya yang diindikasi memiliki pengaruh terhadap cost of financial distress seperti profitabilitas, good corporate governance, dan sebagainya. Penelitian selanjutnya dapat menggunakan sektor lain dan model prediksi cost of financial distress yang diduga lebih akurat, seperti interest coverage ratio, dan sebagainya.

Dalam meningkatkan kinerja perusahaan, hasil dari penelitian ini dapat digunakan sebagai bahan pertimbangan yaitu dengan meningkatkan ekspansi perusahaan serta tetap memantau tingkat likuiditas. Calon investor dapat mempertimbangkan dan memperhatikan tinggi rendahnya ukuran perusahaan dan likuiditas pada perusahaan terkait. Perusahaan yang likuiditasnya rendah serta ukuran perusahaan yang tinggi dianjurkan untuk dipilih oleh investor.

\section{DAFTAR PUSTAKA \\ Buku}

Fahmi, I. (2014). Analisis Laporan Keuangan (4th ed.). Alfabeta.

Hery. (2016). Analisis Laporan Keuangan. Jakarta: PT Gramedia Widiasarana Indonesia.

\section{Jurnal}

Aisyah, N. N., Kristanti, F. T., \& Zultilisna, D. (2017). Pengaruh Rasio Likuiditas, Rasio Aktivitas, Rasio Profitabiltas, dan Rasio Leverage Terhadap Financial Distress. EProceeding of Management, 4(1), 411419.

Branch, B. (2002). The Costs of Bankruptcy A Review. International Review of 
Financial Analysis, 11, 39-57.

Elloumi, F., \& Gueyié, J. P. (2001). Financial Distress and Corporate Governance: an Empirical Analysis. MCB University Press, 1(1), 15-23.

Haq, S., Arfan, M., \& Siswar, D. (2013). Analisis Rasio Keuangan dalam Memprediksi Financial Distress (Studi pada Perusahaan yang Terdaftar di Bursa Efek Indonesia). Jurnal Akuntansi Pascasarjana Universitas Syiah Kuala, 2(1), 37-46.

Kristanti, F. T. (2015). The Test of Gender Diversity and Financial Structure to The Cost of Financial Distress: Evidence From Indonesian Family Business. Globalilluminators Publishing Full Paper Proceeding, 2(April), 554-565.

Kristanti, F. T. and Effendi, N. (2017) 'A Survival Analysis of Indonesian Distressed Company Using Cox Hazard Model', 11, pp. 157-169.

Kristanti, F. T. and Isynuwardhana, D. (2018) 'Survival Analysis of Industrial Sectors in Indonesia Companies', 22(1), pp. 23-36.

López-gracia, J., \& Sánchez-andújar, S. (2007). Financial Structure of the Family Business: Evidence From a Group of Small Spanish Firms. Family Business Review, 20(4), 269-287.

Rudianto. (2013). Akuntansi Manajemen Informasi Untuk Pengambilan Keputusan Strategis. Jakarta: Erlangga.

Saleh, A., \& Sudiyatno, B. (2013). Pengaruh Rasio Keuangan untuk Memprediksi Probabilitas Kebangkrutan pada Perusahaan Manufaktur yang Terdaftar di Bursa Efek Indonesia. Dinamika Akuntansi, Keuangan Dan Perbankan, 2(1), 82-91.

Susilawati, D., Sofianty, D., \& Sukarmanto, E. (2017). Pengaruh Profitabilitas, Ukuran Perusahaan dan Leverage Terhadap
Financial Distress Pada Perusahaan yang Terdaftar di Bursa Efek Indonesia (BEI). Prosiding Akuntansi Universitas Islam Bandung, 3(2), 208-214.

Wardhani, R. A., \& Muid, D. (2017). Pengaruh Agresivitas Pajak, Ukuran Perusahaan dan Profitabilitas Terhadap Corporate Social Responsibility, 6, 1-10.

Widhiari, N. L. M. A., \& Merkusiwati, N. K. L. A. (2015). Pengaruh Rasio Likuiditas, Leverage, Operating Capacity, dan Sales Growth Terhadap Financial Distress. EJurnal Akuntansi Universitas Udayana, 11(2), 456-469.

Wijantini. (2007). The Indirect Costs of Financial Distress in Indonesia. Gajah Mada International Journal of Business, 9(2), 157-186.

Wijarnarto, H., \& Nurhidayati, A. (2016). Pengaruh Rasio Keuangan dalam Memprediksi Financial Distress pada Perusahaan di Sektor Pertanian dan Pertambangan yang Terdaftar di Bursa Efek Indonesia. Jurnal Akuntansi Dan Bisnis, 3(1), 86-105. 
Journal Accounting and Finance

Edisi Vol. 3 No. 2 September 2019

Universitas Telkom 